\title{
Effect of lycopene against gastroesophageal reflux disease in experimental animals
}

\author{
Arvind Kumar Giri, Jitendra Kumar Rawat, Manjari Singh, Swetlana Gautam and Gaurav Kaithwas*
}

\begin{abstract}
Background: Lycopene is a robust antioxidant with significant antiulcer activity. Henceforth, the present study was ventured to elucidate the effect of lycopene on experimental esophagitis.

Methods: Groups of rats were subjected to forestomach and pylorus ligation with subsequent treatment with lycopene (50 and $100 \mathrm{mg} / \mathrm{kg}$, po) and pantoprazole (30 mg/kg, po).

Results: Treatment with lycopene evidenced sententious physiological protection when scrutinized for pH, acidity (total and free), volume of gastric juices and esophagitis index. Lycopene further embarked diminishing effect on oxidative stress through synchronising lipid and protein peroxidation along with regulating the enzymatic activity of SOD and catalase. Lycopene also modified the levels of immunoregulatory cytokines (IL- 1 $\beta$ and IL-6) favourably. The dose dependent efficacy of lycopene in the current experimental condition was also attested when exemplified morphologically through scanning electron microscopy.

Conclusion: From the current line of evidences, it was concluded that lycopene can impart momentous protection against experimental esophagitis by wrapping up the reactive oxygen species and through dual inhibition of the arachidonic acid pathway.
\end{abstract}

Keywords: Anti-inflammatory, Dual inhibitors, Esophagitis, GERD, Interleukin-6, Oxidative stress, Pantoprazole

\section{Background}

Gastroesophageal reflux disease (GERD) is a complex anarchy with the potential for developing esophagitis, esophageal strictures and baretts esophagitis [1]. The situation commences due to reflux of gastric content into esophagus implying to mucosal devastation. Inductive agents in the refluxate are mainly responsible for mucosal damage in GERD. The agents provoke a negotiator release from mucosal and submucosal cells evoking inflammatory reactions resulting in visceral hypersensitivity along with other associated symptoms [2,3]. Abnormal antirefluxate barrier and luminal clearance mechanism results in prolonged contact of refluxate to esophageal mucosa and appears to be responsible for the morphological changes in the esophageal membrane of GERD patients $[4,5]$. Proton pump inhibitors (PPI) and histaminergic - 2 (H-2) blockers are the first line therapies in clinical management of GERD. Due to relapsing nature of disease, clinical management of

\footnotetext{
* Correspondence: gauravpharm@hotmail.com

Department of Pharmaceutical Sciences, School of Biosciences and Biotechnology, Babasaheb Bhimrao Ambedkar University, Raebareli Road, Lucknow 226 025, UP, India
}

GERD is difficult and require prolonged therapy [6]. Moreover, weak inhibitory activity in early phase and less effectiveness of therapy within initial hours of dosing are additional causes for therapeutic relapse in GERD [7].

Some classical inflammatory products like prostanoids and reactive oxygen species (ROS) are considered being critical negotiators in the pathogenesis of clinical GERD [8]. Participation of ROS through free radicals and inflammatory mediators including various cytokines is a well studied phenomenon in case of experimental esophagitis as well [9]. Lycopene is one of the most robust antioxidant with singlet oxygen quenching ability. Lycopene can upregulate the antioxidant electrophile/antioxidant response elements and is reported to have significant antiinflammatory potential as well [10]. In addition to above stated, lycopene is reported to have significant inhibitory effect on the gastric acid secretion followed by efficacy against $H$. pylori infection. Recently, lycopene was also evaluated for its efficacy in oral submucosal fibrosis [11-13]. In view of above and in quest of our continuous search for therapeutic alternatives for GERD, we hypothesize that lycopene by 
virtue of its antioxidant and antiinflammatory property can demonstrate a significant protection in management of GERD, and same was explored through present preclinical investigation.

\section{Methods}

Drugs and chemicals

Lycopene was received as a gift sample from Herbo Nutra Pharmaceuticals Limited, New Delhi, India and Pantoprazole (Palozac, Ajanta Pharma Private Limited, Mumbai, India) was procured from the local market. All other chemicals used were of analytical grade and procured from Himedia Laboratories, Mumbai, India.

\section{Animals}

Albino wistar rats (100-140 gm) were obtained from the central animal house and kept in polypropylene cages under standard condition of temperature $\left(22 \pm 5^{\circ} \mathrm{C}\right)$ with $12 \mathrm{~h}$ light/dark cycle and commercial pellet diet with water ad libitum. The experimental protocol was approved by Institutional Animal Ethics Committee (IAEC) (United Institute of Pharmacy, Naini, Allahabad, U.P, India) (Approval No.UIP/IAEC/2014/FEB/01).

\section{Induction of reflux esophagitis}

Groups of male rats $(n=6)$, fasted for $36 \mathrm{~h}$ received normal saline ( $3 \mathrm{ml} / \mathrm{kg}$, p.o.) (Sham control), pantoprazole (30 mg/ $\mathrm{kg}$, p.o.), lycopene $(50 \mathrm{mg} / \mathrm{kg}$ and $100 \mathrm{mg} / \mathrm{kg}$, p.o) [14]. Esophagitis was induced (except in sham control) by ligating the fore stomach and pylorus with 2-0 silk suture. After $12 \mathrm{~h}$, the animals were sacrificed by cervical dislocation. The chest was opened with a midline incision, esophageal and stomach tissue was removed. Stomach was opened along the greater curvature and esophagus was dissected out by extending the dissection line along the major axis. The tissue was washed with normal saline and examined for lesion. Severity of erosions was scored using Table 1 and esophagitis index was calculated by dividing the total score by ten. Volume of gastric juices, total acidity, free acidity and $\mathrm{pH}$ was measured as described previously [15]. Schematic representation of the procedure to be followed for pylorus and forestomach ligation has been already published by our laboratory [16].

\section{Estimation of oxidative stress paradigms}

Tissues were homogenized in ice cold $0.01 \mathrm{M}$ Tris- $\mathrm{HCl}$ buffer ( $\mathrm{pH}$ 7.4) and subjected to the estimations of tissue glutathione (GSH), superoxide dismutase (SOD), catalase, thiobarbituric acid reactive substances (TBARs) and protein

\section{Table 1 Scoring of erosion and severity}

\begin{tabular}{lllll}
\hline Erosion $(\mathrm{mm})$ & 1 or less & $1-2$ & $2-3$ & $>3$ \\
Score & 1 & 2 & 3 & 4 \\
\hline
\end{tabular}

carbonyl using the methods previously established at our laboratory [17-20]. Tissue supernatant was further subjected for estimation of interleukin-1ß (IL-1ß) (K0331212P) and interleukin-6 (IL-6) (K0331229P) using radioimmunoassay kits (Koma Biotech inc, Seoul, Korea).

\section{Morphological evaluation}

Esophageal tissues were evaluated morphologically through scanning electron microscopy using the method established at our laboratory. Briefly, samples were fixed in glutaraldehyde $(2.5 \%)$ followed by washing in phosphate buffer $(0.1 \mathrm{M})$ at $4^{\circ} \mathrm{C}$. Post washing, the tissues were further fixed in osmium tetroxide (1\%) with subsequent washing with phosphate buffer $(0.1 \mathrm{M})$. Subsequently, samples were dehydrated using increasing concentration of acetone (30\%, 50\%, 70\%, 90\%, 95\%, and 100\%). Samples were air dried and mounted to aluminium stub with adhesive tape and observed under scanning electron microscope (JEOLJSM-6490LV) [21].

\section{In-vitro COX and LOX inhibition assay}

Lycopene and pantoprazole were assayed for COX-1, COX-2 and 15-LOX inhibitory activity using a COXinhibitor screening kit (Catalog No.760111) and LOXinhibitor screening kit (Catalog No. 760700); Cayman Chemical Company, USA, following manufacturer's protocol. Stock solution of lycopene (10\% CMC) and pantoprazole were prepared in water for injection and further dilutions were made up to a concentration of $1 \mu \mathrm{g} / \mathrm{ml}$. Percentage inhibition was calculated by comparing the absorbance intensities, measured spectrophotometrically with a ELISA plate reader (ALERE Microplate Reader, AM-2100) at 590 and $490 \mathrm{~nm}$ for COX and LOX respectively. Test was performed in triplicate.

\section{Statistical analysis}

All data are presented as mean \pm SD and analyzed by one way ANOVA followed by Bonferroni test for possible significance identification between the various groups. $\mathrm{P}<0.05, \mathrm{P}<0.01, \mathrm{P}<0.001$ were considered statistically significant. Statistical analysis was carried out using Graph pad instat software (3.2), San Diego, California.

\section{Results}

The present inquisition was ventured to arbitrate the effect of lycopene on pylorus and forestomach ligation induced reflux esophagitis in rats. Esophagitis control group was accorded with esophageal inflammation, edema, lesions and oral administration of lycopene incomparably ruled out the reflux esophagitis.

Lycopene (50 and $100 \mathrm{mg} / \mathrm{kg}$ ) momentously repressed esophagitis in experimental animals as illustrated through conspicuous reduction in the free acidity, total acidity, 
Table 2 Effect of pantoprazole and lycopene on pH, volume of gastric juices total acidity, free acidity and esophagitis index in experimental animals

\begin{tabular}{|c|c|c|c|c|c|c|}
\hline Group & Treatment & Intestinal pH & $\begin{array}{l}\text { Volume of gastric juices } \\
(\mathrm{ml} / 100 \mathrm{~g})\end{array}$ & $\begin{array}{l}\text { Total acidity } \\
(\mathrm{mEq} / \mathrm{l})\end{array}$ & $\begin{array}{l}\text { Free acidity } \\
(\mathrm{mEq} / \mathrm{l})\end{array}$ & $\begin{array}{l}\text { Esophagitis } \\
\text { index }\end{array}$ \\
\hline Group-I & $\begin{array}{l}\text { Sham control (Normal saline, } \\
3 \mathrm{ml} / \mathrm{kg}, \text { p.o) }\end{array}$ & $\begin{array}{l}3.55 \pm t \\
0.31^{* * *}\end{array}$ & $2.58 \pm 0.38(14.00)$ & $\begin{array}{l}29.39 \pm 0.97^{* * *} \\
(18.95)\end{array}$ & $\begin{array}{l}20.99 \pm 1.31^{* * *} \\
(36.43)\end{array}$ & $\begin{array}{l}0.38 \pm 0.35^{* * *} \\
(87.46)\end{array}$ \\
\hline Group-II & $\begin{array}{l}\text { Esophagitis control (Normal } \\
\text { saline, } 3 \mathrm{ml} / \mathrm{kg}, \mathrm{p} . \mathrm{o} \text { ) }\end{array}$ & $2.73 \pm 0.28$ & $3.00 \pm 0.45$ & $36.26 \pm 0.65$ & $33.02 \pm 0.98$ & $3.03 \pm 0.34$ \\
\hline Group-III & Lycopene (50 mg/kg,p.o) & $\begin{array}{l}3.65 \pm \\
0.23^{* * *}\end{array}$ & $1.57 \pm 0.12(47.66)$ & $\begin{array}{l}30.056 \pm 0.93^{* * *} \\
(17.10)\end{array}$ & $\begin{array}{l}26.32 \pm 1.14^{* * *} \\
(20.29)\end{array}$ & $\begin{array}{l}1.33 \pm 0.12^{* * *} \\
(56.10)\end{array}$ \\
\hline Group-IV & Lycopene (100 mg/kg,p.o) & $\begin{array}{l}4.00 \pm \\
0.34^{* * *}\end{array}$ & $1.87 \pm 0.12(37.66)$ & $\begin{array}{l}28.26 \pm 0.79^{* * *_{a}} \\
(20.06)\end{array}$ & $\begin{array}{l}25.79 \pm 1.09^{* * *} \\
(21.89)\end{array}$ & $\begin{array}{l}1.17 \pm 0.16^{* * *} \\
(61.38)\end{array}$ \\
\hline Group-V & Pantoprazole (30 mg/kg,p.o) & $\begin{array}{l}3.92 \pm \\
0.30^{* * * *}\end{array}$ & $1.35 \pm 3.40(55.00)$ & $\begin{array}{l}26.99 \pm 1.36^{* * *} \\
(25.56)\end{array}$ & $\begin{array}{l}22.32 \pm 1.14^{* * *} \\
(32.40)\end{array}$ & $\begin{array}{l}0.77 \pm 0.16^{* * *} \\
(74.59)\end{array}$ \\
\hline
\end{tabular}

Each group contains six animals. Values are represented as mean \pm SD. Statistical significance compared to toxic control using one-way ANOVA followed by Bonferroni test ( $\left.{ }^{* *} P<0.001\right)$. Values in parenthesis represent percentage inhibition.

Statistical significance compared between lycopene $(50 \mathrm{mg} / \mathrm{kg})$ and lycopene $(100 \mathrm{mg} / \mathrm{kg})$ using one-way ANOVA followed by Bonferroni test $\left({ }^{\mathrm{a}} P<0.05\right)$.

gastric volume along with esophagitis index analogues to esophagitis control (Table 2). Experimental esophagitis perceived a significant diminution in the enzymatic activity of SOD and catalase, which were subsequently restored after lycopene. The tissue GSH levels were observed to be decreased in esophagitis control $(3.69 \pm 0.10)$ group and same was dose dependently replenished by lycopene (Table 3 ). When evaluated biochemically, lycopene also demonstrated marked restoration of antioxidant defence system in comparison to esophagitis control. There was a momentous increase in TBARS generation $(5.17 \pm 0.01 \mathrm{nmol}$ of $\mathrm{MDA} / \mathrm{mg}$ of protein) in esophagitis control in collation to sham control $(1.20 \pm 0.06 \mathrm{nmol}$ of $\mathrm{MDA} / \mathrm{mg}$ of protein) indicating ROS generation and oxidative stress. Administration of lycopene (50 and $100 \mathrm{mg} / \mathrm{kg}$ ) and pantoprazole (30 mg/kg) significantly repressed lipid peroxidation manifested by decreased TBARS levels, i.e. $3.03 \pm 0.03,2.84 \pm 0.04$ and $3.28 \pm 0.03 \mathrm{nmol}$ of $\mathrm{MDA} / \mathrm{mg}$ of protein respectively (Table 3). A significant increase in protein carbonyl content was also observed in esophagitis control in comparison to sham control and lycopene treatment was evident with marked effect on it as well (Table 3). When observed for presence of immunoregulatory markers (IL-1 $\beta$ and IL-6), a momentous upsurge was observed in esophagitis control and same was re-established in a dose dependent manner by administration of lycopene (Table 4).

Considering the efficiency of lycopene to combat various immunoregulatory markers, efficacy of lycopene to inhibit COX-1, COX-2 and 15-LOX was evaluated. Lycopene demonstrated $69.09 \pm 6.47,78.63 \pm 7.54$ and $33.36 \pm 2.10 \%$ inhibitory activities against COX-1, COX-2 and 15-LOX respectively.

Sententious morphological alterations were noticed in esophagitis control group when monitored morphologically and consequent administration of lycopene manifested pronounced protection against the same (Figure 1).

\section{Discussion and conclusions}

GERD is defined as condition that spring up due to reflux of gastric contents into esophagus leading to mucosal damage through ROS and subsequently oxidative stress [9]. In present study, we observed significant protection by lycopene (exogenous antioxidant) against experimental esophagitis. The gastric content is a major factor in

Table 3 Effect of pantoprazole and lycopene on biochemical markers of oxidative stress in experimental animals

\begin{tabular}{|c|c|c|c|c|c|c|}
\hline Group & Treatment & $\begin{array}{l}\text { Glutathione } \\
\text { (mg \%) }\end{array}$ & $\begin{array}{l}\text { Superoxide } \\
\text { dismutase } \\
\text { (unit of SOD/ } \\
\text { mg of protein) }\end{array}$ & $\begin{array}{l}\text { Catalase } \\
\text { (nM of } \\
\mathrm{H}_{2} \mathrm{O}_{2} / \mathrm{min} \\
\text { /mg of protein) }\end{array}$ & $\begin{array}{l}\text { Thiobarbituric acid } \\
\text { reactive substances } \\
\text { (nM of MDA/mg } \\
\text { of protein) }\end{array}$ & $\begin{array}{l}\text { Protein } \\
\text { carbonyl } \\
(\mathrm{nM} / \mathrm{ml})\end{array}$ \\
\hline Group-l & Sham control (Normal saline,3 ml/kg, p.o) & $4.71 \pm 0.42^{* * *}$ & $110.39 \pm 66.13$ & $4.45 \pm 0.40^{* * *}$ & $1.20 \pm 0.06^{* * *}$ & $48.18 \pm 1.82^{* * *}$ \\
\hline Group-II & Esophagitis control (Normal saline,3 ml/kg, p.o) & $3.69 \pm 0.10$ & $64.21 \pm 31.76$ & $2.58 \pm 0.71$ & $5.17 \pm 0.01$ & $162.12 \pm 1.74$ \\
\hline Group-III & Lycopene (50 mg/kg, p.o) & $4.78 \pm 0.10^{* * *}$ & $71.70 \pm 17.90$ & $4.05 \pm 0.78^{* *}$ & $3.28 \pm 0.07^{* * *}$ & $129.39 \pm 5.04^{* * *}$ \\
\hline Group-IV & Lycopene (100 mg/kg,p.o) & $4.02 \pm 0.20^{c}$ & $64.68 \pm 15.09$ & $4.10 \pm 0.37^{* * *}$ & $3.03 \pm 0.03^{* * * c}$ & $112.50 \pm 3.00^{* * * c}$ \\
\hline Group-V & Pantoprazole (30 mg/kg, p.o) & $4.26 \pm 0.05^{* *}$ & $67.89 \pm 27.06$ & $3.44 \pm 0.38$ & $2.84 \pm 0.04^{* * *}$ & $98.26 \pm 3.07^{* * *}$ \\
\hline
\end{tabular}

Each group contains six animals. Values are represented as mean \pm SD.

Statistical significance compared to toxic control using one-way ANOVA followed by Bonferroni test $\left({ }^{* *} P<0.01\right.$, and $\left.{ }^{* * *} P<0.001\right)$.

Statistical significance compared between lycopene $(50 \mathrm{mg} / \mathrm{kg})$ and lycopene $(100 \mathrm{mg} / \mathrm{kg})$ using one-way ANOVA followed by Bonferroni test $\left({ }^{\mathrm{C}} P<0.001\right)$. 
Table 4 Effect of pantoprazole and lycopene on immunoregulatory cytokines in esophageal tissues of experimental animals

\begin{tabular}{llll}
\hline S. No. & Treatment & IL-1 $\mathbf{\beta}$ (pg/ml) & IL-6 (pg/ml) \\
\hline Group-I & Sham control (Normal saline,3 ml/kg,p.o) & $758.98 \pm 30.61^{* * *}$ & $17673.16 \pm 196.4^{* * *}$ \\
Group-II & Esophagitis control (Normal saline,3 ml/kg,p.o) & $2595.9 \pm 210.93$ & $43429.33 \pm 868.9$ \\
Group-III & Lycopene (50 mg/kg,p.o) & $755.68 \pm 82.67^{* * *}$ & $25878.2 \pm 405.1^{* * *}$ \\
Group-IV & Lycopene (100 mg/kg,p.o) & $788.86 \pm 38.19^{* * *}$ & $22055.31 \pm 779.86^{* * *}$ \\
Group-V & Pantoprazole (30 mg/kg,p.o) & $612.98 \pm 44.47^{* * *}$ & $15611.14 \pm 411.82^{* * *}$ \\
\hline
\end{tabular}

Each group contains six animals. Values are represented as mean \pm SD. Statistical significance compared to toxic control using one-way ANOVA followed by Bonferroni test $(* * * 0<0.001)$.

Statistical significance compared between lycopene $(50 \mathrm{mg} / \mathrm{kg})$ and lycopene $(100 \mathrm{mg} / \mathrm{kg})$ using one-way ANOVA followed by Bonferroni test $\left({ }^{\mathrm{C}} P<0.001\right)$.

pathogenesis of GERD and lycopene was observed to have marked effect on that through decrease in acidity (total and free), gastric volume and thereby subsequent increase in $\mathrm{pH}$. After lycopene treatment modulation in $\mathrm{pH}$ and acidity of gastric content was also reflected through decrease in esophagitis index. Physiological changes as observed in the present study, suggest, positive modulation in GERD by lycopene.

Precedent studies have unfolded the role of free radicals in pathogenesis of GERD in experimental animals with
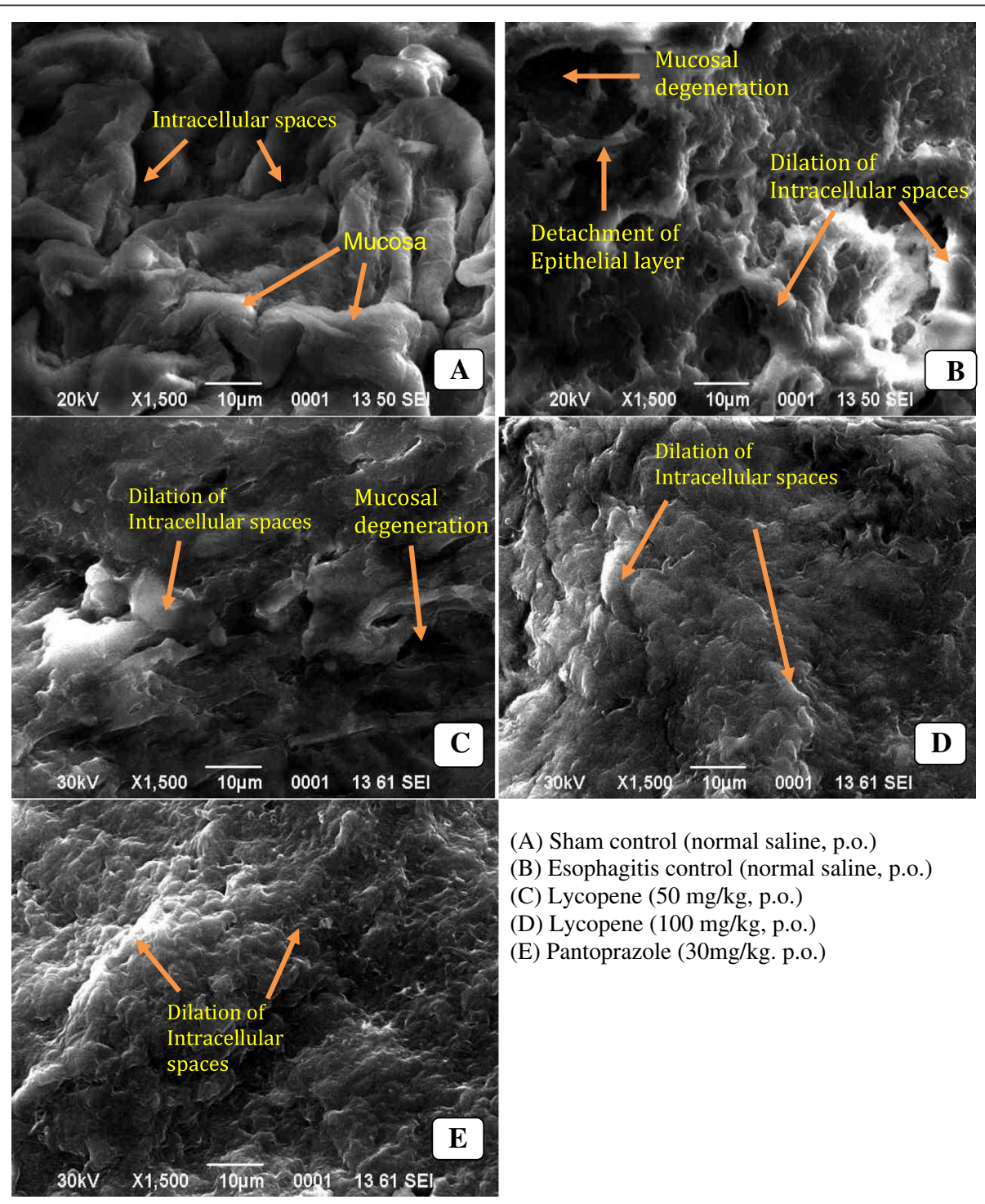

(A) Sham control (normal saline, p.o.)

(B) Esophagitis control (normal saline, p.o.)

(C) Lycopene $(50 \mathrm{mg} / \mathrm{kg}$, p.o.)

(D) Lycopene $(100 \mathrm{mg} / \mathrm{kg}$, p.o.)

(E) Pantoprazole (30mg/kg. p.o.)

Figure 1 Morphological evaluation of esophageal tissues using scanning electron microscopy. 
concomitant increase in levels of malondialdehyde (MDA) [22]. MDA is a stable product of lipid peroxidation and is a sensitive and reactive marker of membrane damage. MDA forms a colour complex with thiobarbituric acid (TBA) which can be scrutinized spectrophotometrically. In the present study, we observed momentous increase in MDA in esophagitis control, advocating active involvement of ROS after forestomach and pylorus ligation, which is in alignment to foregoing reports [21]. It would be apropos to mention that lycopene treatment momentously decreased lipid peroxidation as attested by decrease in MDA formation through TBA assay. GSH is the most profuse low molecular weight thiol and is an omniprest tripeptide, involved in wide range of enzymatic reaction. The function of GSH in an oxidation reduction process is to act as reductant, resulting in formation of glutathione disulphide (GSSG). In first few hours of oxidative stress, free radicals damage leads to consumption of GSH, directing decreased GSH level and therefore it is considered a marker of short term oxidative stress [23]. Decreased levels of GSH represent its increased consumption by the cells as a consequence of ROS generation. Results from the present study depict that lycopene treatment significantly helped to restore the GSH in dose dependent manner, suggesting either restored biogenesis of GSH or decreased oxidative stress.

The SOD and catalase are antioxidant enzymes with induct radical scavenging activity. SOD interacts with superoxide radical to form $\mathrm{H}_{2} \mathrm{O}_{2}$, which is subsequently catabolised by catalase to molecular oxygen and water [24]. Catalase is a hemeprotein and protects the tissue from deleterious effects of highly reactive hydroxyl radicals $[25,26]$. In present study, a simultaneous decrease in SOD and catalase activity after ligation of pyloric end and forestomach was observed. This decrease in enzymatic activity of SOD and catalase could be attributed to increased utilization, in consequence to oxidative stress. Treatment with lycopene restored the diminished levels of catalase and SOD. The free radical attack can destroy all types of biological molecules including proteins, lipids and DNA. When proteins are oxidised either by $\alpha$ amidation pathway or by oxidation of glutamide side chain, carbonyl group is produced on a protein side chain. Hence the occurrence of protein carbonyl content and amino acid residue is one of the most general indicators of protein oxidation. Therefore, protein carbonyl is universally used as marker of protein oxidation $[27,28]$. In the present study pylorus and forestomach ligation significantly increased protein carbonyl level, indicating protein oxidation. Subsequent treatment with lycopene was observed for decrease in protein carbonyl levels in esophageal tissues. From above line of evidences, one can derive that lycopene could be instrumental physiologically and biochemically in the management of esophageal reflux in experimental conditions.

Foregoing, preclinical and clinical studies on GERD have shown that the immune and inflammatory responses are characterized by specific cytokine and chemokines profiles (IL-1 $\beta$, IL-2, IL- 6 and many more). Moreover, reflux of acid into the esophagus, release immunoregulatory cytokines along with damage of mucosal lining; further strengthen the theory that GERD is an auto-immune disorder with

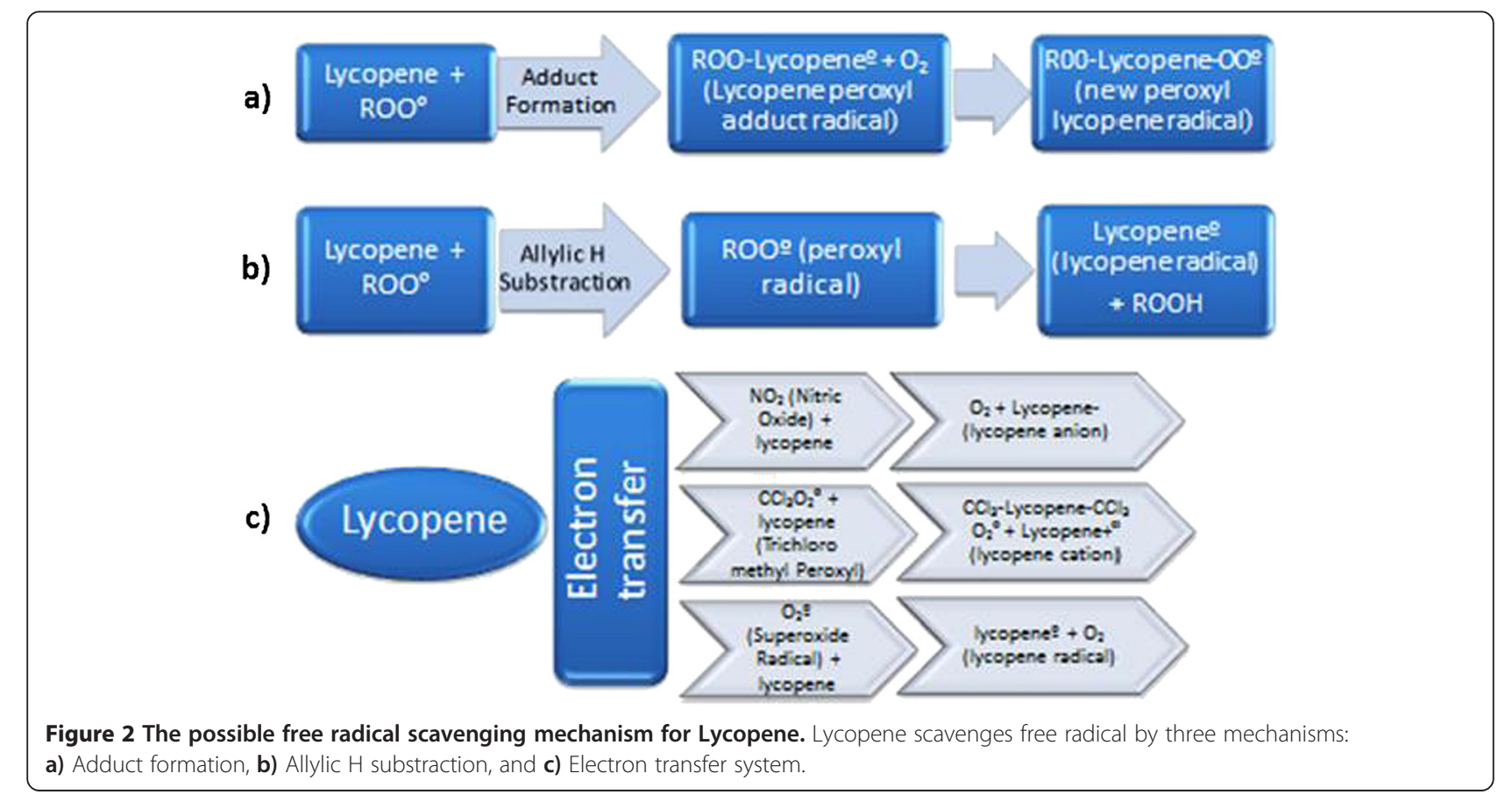


inflammatory participation [29-31]. Considering the physiological importance of immunoregulatory cytokines, we quantified IL-1 $\beta$ and IL- 6 in the esophageal tissues. IL-1 $\beta$ is a member of IL-1 cytokine family and is mainly produced by the activated macrophages. IL- $1 \beta$ is involved in variety of activities including cell proliferation, differentiation and apoptosis. The IL-6 is secreted by various cells like T-cells, $\beta$-cells, microglia, fibroblast, endothelial cells, neurons and astrocytes. IL- 6 is originally identified as $\beta$-cells differentiation factor and is synthesized in response to IL-1 $\beta$. IL-6 has an important role in host reaction to inflammation which results in the synthesis of acute inflammatory proteins. IL- 6 and IL-1 $\beta$ are proinflammatory cytokines involved in the acute phase of immune responses. Both IL-1 $\beta$ and IL- 6 can stimulate the inflammatory and autoimmune response in many diseases like diabetes, cancer and esophagitis [32]. The current line of evidences suggest the over expression of immunoregulatory cytokines (IL $-1 \beta$ and IL-6) in response to forestomach and pylorus ligation (esophagitis control) which is in corroboration to the precedent reports and also suggest utmost immunocompromised status [33]. The lycopene treatment restored the levels of IL-1 $\beta$ and IL-6 to a significant level further strengthening the hypothesis outlined in the current study.

The prolong contact of esophageal mucosal membrane with acid and pepsin due to the impaired antireflux barrier can lead to morphological changes in it and to investigate the same, esophageal tissues were investigated for morphological changes using SEM [4]. Significant ultrastructural changes, including dilation of intracellular spaces, extensive erosion of esophageal mucosa, detachment of epithelial layer and mucosal degeneration, as reputed by precedent studies, were also evident in the current experiment. Treatment with lycopene demonstrated significant protection through restoring the normal morphology of the esophageal tissues.

When contemplated for the in-vitro COX and LOX inhibition assay, lycopene evidenced a significant inhibition of COX-1 and COX-2 enzymes with considerable inhibition of 15-LOX, suggesting dual inhibition of the arachidonic acid pathway. It would be appropriate to mention that dual inhibitors of arachidonic acid metabolism are established to have excellent gastrointestinal safety profile and thereby lycopene could offer a fringe benefit in management of gastrointestinal disorders.

Lycopene is a non provitamin A carotenoid with polyisoprenoid structure [34,35]. It is a lipophilic compound with high number of conjugated diene and is one of the most robust antioxidant with a singlet oxygen quenching ability. Several lines of evidence suggest that lycopene can upregulate the antioxidant electrophile/antioxidant response element, which stimulates the production of phase II detoxifying antioxidant enzymes that protect the cells from ROS [10]. Lycopene can react with variety of radicals through adduct formation, electron transfer and allylic $\mathrm{H}$ subtraction. The adduct genesis results in configuration of resonance-stabilised carbon centered peroxy radical, where a free radical can attach to the polyene chain (through highly conjugated double bonds of lycopene) to form a lycopene peroxyl (ROO-lycopene ${ }^{\circ}$ ) radical adduct. ROOlycopene ${ }^{\circ}$ may possibly react with $\mathrm{O}_{2}$ to form ROOlycopene- $\mathrm{OO}^{\circ}$ (Figure 2). Through electron transfer mechanism, lycopene can form radicals like cation radical, anion radical or alkyl radical depending upon the type of radical involved in the process. Another method through which lycopene can curb down the ROS is hydrogen abstraction (allylic $\mathrm{H}$ substration) leading to formation of lycopene radical [36-38] (Figure 2).

As enumerated from the current experimental evidences, it became settled that lycopene can offer momentous protection against the experimental esophagitis, and the same could be attributed to its ROS scavenging along with antiinflammatory (dual inhibitory) potential. Lycopene is a well established antioxidant and is under clinical investigation for various ailments including prostate cancer. Authors would like to comment that the present preclinical finding further strengthen the candidature of lycopene against gastroesphageal cancer and other similar ailments.

\section{Competing interests}

The authors declare that they have no competing interests.

\section{Authors' contributions}

AKG: Carried out the bench work. JKR and MS: Compiled the data, statistical analysis and organised the manuscript. SG: Contributed towards bench work and statistical analysis. GK: Designed the study and prepared the manuscript. All authors read and approved the final manuscript.

\section{Acknowledgement}

Authors are thankful to Herbo Nutra Private Limited New Delhi, India for providing lycopene as a generous gift sample; Authors would like to thanks University Grants Commission for providing Rajiv Gandhi National Fellowship to MS (RGNF-2013-38150), JKR (RGNF-2013-51936) and SW (RGNF-2013-48716); Thanks are due to Dr. V Elongovan, Coordinator, Central Instrumentation Facility for his efforts for the SEM analysis.

\section{Funding declaration}

The work presented in the current manuscript was supported by the funds from Department of Pharmaceutical Sciences, Babasaheb Bhimrao Ambedkar University, Lucknow.

Received: 16 August 2014 Accepted: 23 March 2015

Published online: 09 April 2015

\section{References}

1. Locke GR, Talley NJ, Fett SL, Zinsmeister AR, Melton LJ. Prevalence and clinical spectrum of gastroesophageal reflux: apopulation-based study in Olmsted County, Minnesota. Gastroenterology. 1997;112:1448-56.

2. Pereira RDS. Regression of gastroesophageal reflux disease symptoms using dietary supplementation with melatonin, vitamins and aminoacids: comparis on with omeprazole. J Pineal Res. 2006;41(3):195-200.

3. Souza RF, Huo X, Mittal V. Gastroesophageal reflux might cause esophagitis through a cytokine-mediated mechanism rather than caustic acid injury. Gastroenterology. 2009;137(5):1776-84.

4. Bredenoord AJ. Mechanisms of reflux perception in gastroesophageal reflux disease: a review. Am J Gastroenterol. 2012;107:8-15. 
5. Zaika E, Bhardwaj V, Wei J, Washington MK, Souza R, El- Rifai W, et al. Proinflammatory cytokines and bile acids upregulate $\Delta \mathrm{Np} 73$ protein, an inhibitor of p53 and p73 tumor suppressors. PLoS One. 2013;8(5):e64306.

6. Mitushing S, Seok Jang J, Yoshizawa Y. Proton pump inhibitor therapy before and after endoscopic submucosal dissection: a review. Diagn Ther Endosc. 2012, Article ID791873, 11 pages. doi:10.1155/2012/791873.

7. Kuster E, Ros E, Toledo-Pimentel V. Predictive factorsof the long term outcome in gastro-oesophageal reflux disease:six year follow up of 107 patients. Gut. 1994;35(1):8-14

8. Jiménez P, Piazuelo E, Sánchez MT, Ortego J, Soteras F, Lanas A. Free radicals and antioxidant systems in reflux esophagitis and Barrett's esophagus. World J Gastroenterol. 2005;11:2697-703.

9. Yoshida N. Inflammation and oxidative stress in gastroesophageal reflux disease. J Clin Biochem Nutr. 2007;5:13-23.

10. Palozza P, Catalano A, Simone R, Cittadini A. Lycopene as a regulator of redox signalling. Acta Biochim Pol. 2012;5(1):21-5.

11. Karemore TV, Motwani M. Evaluation of the effect of newer antioxidant lycopene in the treatment of oral submucous fibrosis. Indian J Dent Res. 2012;23(4):524-8.

12. Shidfar F, Agah S, Ekhlasi G, Salehpour A, Ghourchian S. Lycopene an adjunctive therapy for Helicobacter pylori eradication: a quasi-control trial. J Complement Integr Med. 2012, 9, Article 14. doi: 10.1515/1553-3840.1588

13. Milani C, Maccari M, Mosconi P. Action of lycopene in the experimental gastric ulcer. Pharmacology. 1970;4(6):334-40.

14. Al-Malki AL. Synergestic effect of lycopene and Melatonin against the genesis of oxidative stress induced by cyclophosphamide in rats. Toxicol Ind Health. 2014;30:570-5.

15. Arya E, Saha S, Saraf SA, Kaithwas G. Effect of Perilla frutescens Fixed Oil on Experimental Esophagitis in Albino Wistar Rats. BMRI. 2013, Article ID 981372, 6 pages. doi.org/10.1155/2013/981372.

16. Khinchi P, Saha S, Saraf SA, Kaithwas G. Combination therapy of gammaaminobutyric acid derivative promotes proton pump inhibitor based healing of reflux esophagitis in animal model. Pharmacol Rep. 2014;25:1-4

17. Raj P, Singh M, Rawat JK, Gautam S, Saraf SA, Kaithwas G. Effect of enteral administration of a-linolenic acid and linoleic acid against methotrexate induced intestinal toxicity in albino rats. RSC Adv. 2014:4:60397-403.

18. Gupta SK, Gautam S, Rawat JK, Singh M, Saraf SA, Kaithwas G. Efficacy of variable dosage of aspirin in combating methotrexate-induced intestinal toxicity. RSC Adv. 2015;5:9354-60.

19. Kumar S, Singh M, Rawat JK, Gautam S, Saraf SA, Kaithwas G. Effect of rutin against gastric esophageal reflux in experimental animals. Toxicol Mech Methods. 2014:24:666-71

20. Kaithwas $G$, Singh P, Bhatia D. Evaluation of in vitro and in vivo antioxidant potential of polysaccharides from Aloe vera (Aloe barbadensis Miller) gel. Drug Chem Toxicol. 2014;37:135-43.

21. Shukla S, Raj P, Kumar A, Kaithwas G. Effect of Monotherapy and Combination Therapy of Pantoprazole and Aprepitant in Gastric Esophageal Reflux Disease in Albino Rats. Sci World J. 2014, Article ID 183147, 7 pages. doi.org/10.1155/2014/183147.

22. Renu N, Kaithwas G, Ramteke PW, Saraf SA. Effect of Linum usitatissimum (linseed/flaxseed) fixed oil on experimental esophagitis in albino rats. Acta Gastroenterol Belg. 2012;75(3):331-5.

23. Stein HJ, Hinder RA, Oosthuizen MMJ. Gastric mucosal injury caused by hemorrhagic shock and reperfusion: protection role of the antioxidant glutathione. Am J Surg. 1990;180:467-74.

24. Singh G, Singh AT, Abrahama A, Bhat B, Mukherjee A, Verma R. Protective effect of Terminaliaarjuna against doxorubicin induced cardio toxicity. J Ethnopharmacol. 2008;117(1):123-9.

25. Kaithwas G, Dubey K, Pillai KK. Effect of Aloe vera (Aloe barbadensis Miller) gel on doxorubicin induced myocardial oxidative stress and calcium overload in albino rats. Indian J Exp Biol. 2011;49(4):260-8.

26. Kaithwas G, Majumdar DK. Invitro antioxidant and in vivo antidiabetic, antihyperlipidemic activity of linseed oil against streptozodocin induced toxicity in albino rats. Eu J Lip Sci Tech. 2012;114(11):1237-45.

27. Chevion M, Berenshtein E, Stadtman ER. Human studies related to protein oxidation: Protein carbonyl content as a marker of damage. Free Radic Res. 2000;33:S99-108

28. Isabella D, Donne R. Protein carbonyl group as biomarker of oxidative stress. Clin Chim Acta. 2003;329:23-38.
29. Fitzgerald RC, Onwuegbusi B, Bajaj-Elliott M, Saeed IT, Burnham WR, Farthing MJG. Diversity in the oesophageal phenotypic response to gastroesophageal reflux: immunological determinants. Gut. 2005;50(4):451-9.

30. Isomoto H, Nishi Y, Wang A, Omagari FT, Katsuhisa. Mucosal concentrations of proinflammatory cytokines and chemokines at gastric cardia: implication of helicobacter pylori infection and gastroesophageal reflux. Am J Gastroenterol. 2004;99:1063-8.

31. Fitzgerald RC. Inflammatory gradient in Barrett's esophagus: implications for disease complications. Gut. 2002;51(3):16-22

32. Burgh RVD, Nijhuis L, Pervolaraki K, Compeer EB, Jongeneel LH, Gijin MV, et al. Defects in Mitochondrial clearance Predispose Human Monocytes to Interleukin- $1 \beta$ Hypersecretion. J Bio Chem. 2014;289(8):5000-12.

33. Rieder F, Cheng L, Harnett KM, Chak A, Cooper GS, Isenberg G. Gastroesophageal reflux disease-associated esophagitis induces endogenous cytokine production leading to motor abnormalities. Gastroenterology. 2007;132(1):154-65.

34. Cevik O, Oba R, Macit C, Cetinel S, Tugce O, Kalya C, et al. Lycopene inhibit caspase -3 activity and reduces oxidative organ damage in rat model of thermal injury. Burns. 2012;38:861-71.

35. Mein JR, Lian F, Wang XD. Biological activity of lycopene metabolites:implication for cancer prevention. Nutr Rev. 2008;66(12):667-83.

36. Kong WK, Khoo HE, Prasad KN, Ismail A, Tan CP, Rajab NF. Revealing the power of the natural red pigment lycopene. Molecules. 2010;15:959-87.

37. Kelkel M, Schumacher M, Dicata M, Diederich M. Antioxidant and Antiproliferative properties of lycopene. Free Radic Res. 2011;45(8):925-40.

38. Solís CT, Chaverrí JP, Ramos MT, Farfán DJ, Salgado AC, García NS, et al. Multiple Molecular and Cellular Mechanisms of Action of Lycopene in Cancer Inhibition. ECAM. 2013, Article ID 705121. 17 pages, doi.org/10.1155/ 2013/705121.

\section{Submit your next manuscript to BioMed Central and take full advantage of:}

- Convenient online submission

- Thorough peer review

- No space constraints or color figure charges

- Immediate publication on acceptance

- Inclusion in PubMed, CAS, Scopus and Google Scholar

- Research which is freely available for redistribution

Submit your manuscript at www.biomedcentral.com/submit
C Biomed Central 